\title{
CLONING AND CHARACTERISATION OF ACC OXIDASE GENE FROM MAS (AA) BANANA
}

\section{Wijenthiran Kunasekaran, Amru Nasrulhaq Boyce and Chandran Somasundram*}

CEBAR, Institute of Biological Sciences, Faculty of Science, University of Malaya, 50603 Kuala Lumpur, Malaysia. Tel: +603 7967 4423, Fax: +6 0379674178

*chandran@um.edu.my. (corresponding author)

Received on 10th December 2011, accepted in revised form 3rd March 2011.

\begin{abstract}
Considerable experimental attention has been given to amplify Mas (AA) ACC oxidase gene from Mas (AA) banana (Genbank accession number: EU106081). ACO gene from Mas (AA) has been compared with other homologous gene by using bioinformatics tools to study the characteristics of the gene such as evolutionary history, binding sites, predicted 3D structure and consensus region of the homologous proteins. The finding shows that Mas ACO is member of iron/ascorbate-dependent oxidase superfamily which requires ascorbate and iron for full activity so that it will meet the all the criteria requires as it is expressed in vivo to produce ethylene.

Abstrak Kaedah tertentu telah digunakan untuk mengamplifikasikan gen Mas (AA) ACC oksidase dari pisang Mas (AA) (Nombor Akses Genbank: EU106081). Gen ACC oksidase adalah dari Mas (AA) telah dibandingkan dengan sepuluh gen homologus yang lain dengan menggunakan peralatan bioinformatik untuk mengkaji ciri-ciri, sejarah evolusi, tapak pengikatan, ramalan struktur 3D dan konsensus protein homologi. Berdasarkan dari penemuan ini, didapati bahawa Mas ACO merupakan ahli keluarga oksidase yang bergantung kepada besi/askorbat untuk menjalankan akitiviti sepenuhnnya yang lengkap sepertimana ianya dihasilkan secara 'in vivo' untuk menghasilkan etilena.
\end{abstract}

(Keywords: ACC Oxidase (ACO), Ethylene, Mas (AA) banana, Musa acuminata, bioinformatics)

\section{INTRODUCTION}

Banana is a member of the genus Musa of the family Musaceae where there are two main wild speciesMusa acuminata and Musa balbisiana. Ethylene produced endogenously exerts a major role in plant growth, development and senescence apparently at regulatory levels of metabolism and can also be described as plants simplest hormone (Lieberman, 1979). The pathway of ethylene biosynthesis proceeds from methionine, through Sadenosylmethionine (SAM) and 1aminocyclopropane-1-carboxylic acid (ACC) to ethylene and that the two main enzymes are ACC synthase (ACS) and ACC oxidase (ACO) (Yang and Hoffman, 1984) and (Abeles et al., 1992). ACO is a type of an oxidative enzyme which carries out the conversion of ACC to ethylene. The first authentic ACO activity in vitro was demonstrated by extracting melon fruit and assaying the enzyme under the conditions for flavanone-3-hydroxylase and this preparation needs Ferum (II) ion and ascorbate for full activity (Ververidis and John, 1991) and the failure of previous attempts of performing in vitro ACO activity was due to the loss of these factors during the enzyme extraction (Fernandez-Maculet and Yang, 1992). $\mathrm{CO}_{2}$ has been identified as the species responsible for the activation of $\mathrm{ACO}$ and proved that $\mathrm{CO}_{2}$ forms a carbamate with an amino group of the enzyme (Fernandez-Maculet et al., 1993). The conservation of histidine residues among the ACO contains critical histidine residues at the active site (Christoffersen et al., 1993). This work focuses on cloning and characterising ACO gene from Mas (AA) banana.

\section{MATERIALS AND METHODS}

\section{Banana material and RNA extraction}

Pulp tissues from dessert variety Mas (AA) banana was used for total RNA extraction (Liu et al., 1998). The RNA sample was dissolved in $100 \mu$ l of SDW before being stored at $-80^{\circ} \mathrm{c}$.

Quantification and estimation of nucleic acid concentration

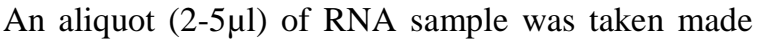
up to $1 \mathrm{ml}$ with SDW to a known dilution (200-500 folds) and placed in a quartz cuvette. Absorbance was measured at 200-320nm using a spectrophotometer (Pharmacia Ultraspec II) against SDW as blank with 
maximum reading at $260 \mathrm{~nm} \quad\left(\mathrm{~A}_{260}\right)$. The concentration was calculated as follows:

RNA concentration $\left(\mu \mathrm{g} . \mu 1^{-1}\right)$ : $40 \mathrm{x}$ dilution factor $\mathrm{x}$ $\mathrm{A}_{260}$

\section{Reverse Transcription Polymerase Chain Reaction (RT-PCR) of ACC Oxidase}

The ACO primers (BACCO) were designed from the conserved region of banana (Pathak et al., 2003) and were commercially made. The sequences of the two primers are as follows:

\section{BACCO Forward} 5' TTTCCGGTTATCGACATGGAGAAGC 3'

\section{BACCO Reverse}

\section{3'AATATTGTAGGTAATTACTATGGG 5'}

\section{Template preparation}

$2 \mu \mathrm{l}$ of total RNA $\left(1 \mu \mathrm{g} \mu \mathrm{l}^{-1}\right)$ were used for the amplification and the reverse transcriptase polymerase chain reaction (RT-PCR) was carried out in a volume of $50 \mu 1$ in a $0.5 \mathrm{ml}$ Eppendorf tube using the Promega AccessQuick ${ }^{\mathrm{TM}}$ RT-PCR system. The reaction mixture was thoroughly mixed and $1 \mu \mathrm{l}$ of AMV Reverse Transcriptase was added by gentle vortexing. RT-PCR was started on a GeneAmp 9600 Thermcycler (Perkin Elmer) with amplification cycles as described: reverse transcription (1cycle) $45^{\circ} \mathrm{c}$ for $45 \mathrm{~min}$, denaturation (1cycle) $95^{\circ} \mathrm{c}$ for 2 min, annealing ( 40 cycles) $95^{\circ} \mathrm{c}, 30 \mathrm{sec}, 60^{\circ} \mathrm{c}, 1 \mathrm{~min}$, $72^{\circ} \mathrm{c}, 2 \mathrm{~min}$, extension (1cycle) $72^{\circ} \mathrm{c}, 7 \mathrm{~min}$, soak cycle (hold) $4^{\circ} \mathrm{c}$, overnight.

\section{Purification of RT-PCR product}

Obtanied cDNA was purified using Perfectprep Gel cleanup system. Gel slice of PCR product was taken and weighed in a micro centrifuge tube. Equal volume of Binding buffer was added and incubated at $50^{\circ} \mathrm{C}$ for 5 to 10 minutes in an Eppendorf Thermomixer at 1000rpm. Equal volume of isopropanol to the original gel slice was mixed by inversion to the dissolved gel slice. $800 \mu 1$ of sample was added to a spin column and centrifuged at 6000rpm for 1 minute filtrate was discarded and $750 \mu$ l of diluted wash buffer was added to the spin column and centrifuged at 6000rpm for 1 minute. Filtrate was discarded and the spin column was centrifuged at $6000 \mathrm{rpm}$ for an additional minute to remove any residual diluted wash buffer. $30 \mu 1$ of elution buffer was added to the centre of the spin column and centrifuged at 6000rpm for 1 minute. Spin column was discarded and purified cDNA was stored at $-80^{\circ} \mathrm{C}$.

\section{Sequencing}

cDNA sequencing of PCR was carried out commercially through BioSynTech Sdn Bhd.

\section{Bioinformatics analysis}

Most of the bioinformatics tools and databases were obtained and accessed through NCBI homepage. Sequence analysis and proteomics tools were accessed on ExPASy (Gasteiger et al., 2003) where conversion of nucleotide sequence to protein sequence and characterization of the sequence was done here. RasMol (Sayle and Milner-White, 1995) protein structure viewing software was used to view the protein's 3D structure generated by Quick Phyre web server (Kelley and Sternberg, 2009).

\section{RESULTS}

RT-PCR with the BACCO primers yielded a single product with a size of $1040 \mathrm{bp}$. Clear products were visible in $1.2 \%$ agarose gel for Mas (AA) RNA. The sequence analysis was done from the complete nucleotide sequence of ACC oxidase from Mas banana. The nucleotide is $100 \mathrm{bp}$ long and includes the entire ACC oxidase coding region consensus pattern ( P-V-I-[DN]-M-E-K-L-X-G-X-E-R-[AEGS]$\mathrm{x}$-[AT]-M-E-x-[IL]-x-D-A-C-E-x-W-G-F-F-E$\mathrm{x}(0,1)-\mathrm{L}-\mathrm{x}(0,1)-\mathrm{N}-\mathrm{H}-\mathrm{G}-\mathrm{I}-[\mathrm{PS}]-\mathrm{x}(2)-\mathrm{L}-[\mathrm{LM}]-\mathrm{D}-[\mathrm{ET}]-$ V-E-[KR]-[LMV]-[NT]-K). The ATG beginning at position 1 is most likely to be the translation initiation codon and the TGA beginning at position 967 is the in-frame termination codon. Prosite scan was done to the protein sequence against PROSITE database to search for biologically relevant sites and signatures.

The scanning process revealed that there are 337 amino acids and further analysis on the sequence revealed that it comprises about 40 negatively charged residues (Asp+Glu) and 28 positively charged residues (Arg+Lys). The Mas ACC oxidase gene sequence has four $\mathrm{N}$-glycosylation site (at residues N111-E114, N165-I168, N199-F202, N308C311), three protein kinase $\mathrm{C}$ phosphorylation site (T7-K9, T132-R134, T167-R169), four Casein kinase II phophorylation site (S91-D94, T132-E135, S240D243, S252-D255), one amidation site (T7-K10) and one N-myristoylation site (G137-S142). 


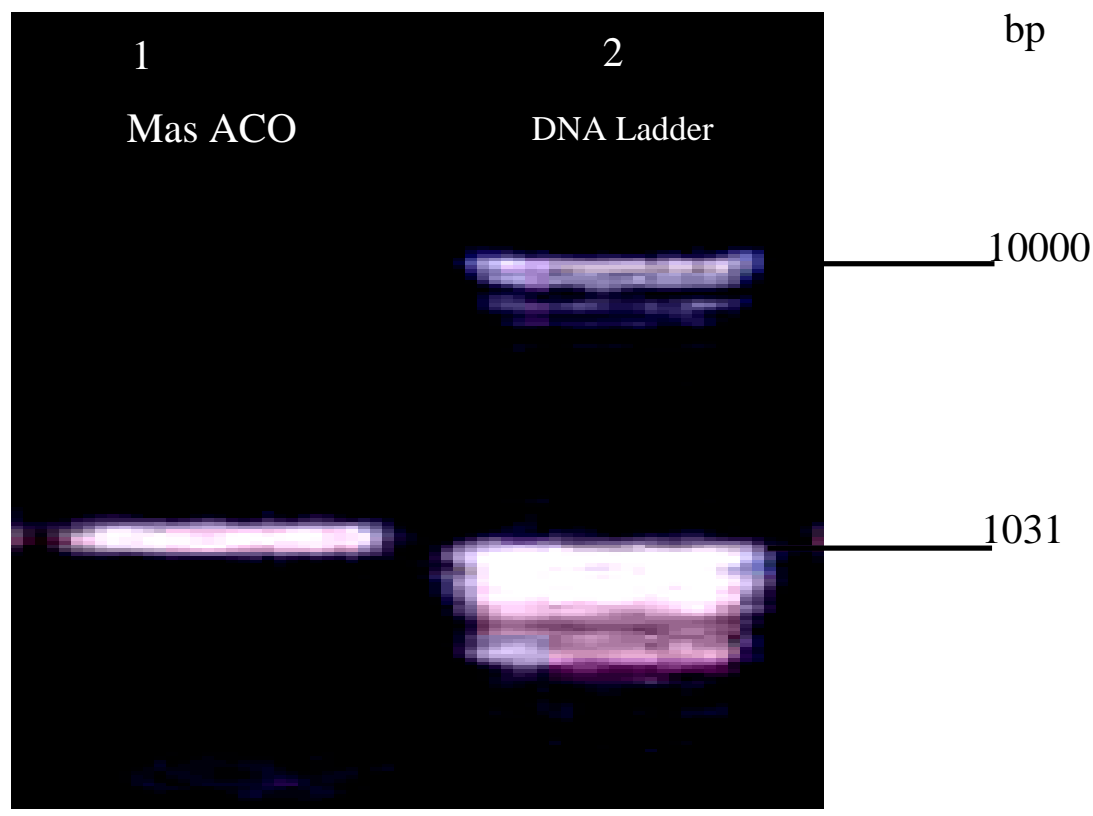

Figure 1: RT-PCR results with BACCO primer for Mas. In Lane 2 is GeneRuler DNA Ladder Mix (Fermentas). Lane 1 is PCR product of 1009 bp generated using primers BACCO for total RNA from Mas (AA).

BLAST (Altschul et al., 1990) homology search revealed the total of 109 blast hits homology. Ten most significant sequences were displayed to show significant to the query sequence Mas ACO gene:

1. 414/427 positive identities (96\%) with $M$. acuminata ACO

2. 414/427 positive identities (96\%) with $M$. acuminata ACO

3. $414 / 427$ positive identities $(96 \%)$ with $M$. acuminata ACO

4. 409/421 positive identities (97\%) with Robusta cultivar ACO

5. 408/422 positive identities (96\%) with $M$. acuminata ACO
6. $410 / 423$ positive identities $(96 \%)$ with $M$. acuminata ACO

7. 339/344 positive identities (98\%) with $M$. acuminata ACO

8. 280/296 positive identities (94\%) with Mangifera indica ACO

9. $125 / 125$ positive identities $(100 \%)$ with $M$. acuminata ACO

10. $125 / 125$ positive identities (100\%) with $M$. acuminata ACO

\footnotetext{
Banana 1 -----------MDSFPVIDMEKLLGRERGAAMEILRDACEKWGFFEIL 37

Banana 2 ---------MDSFPVIDMEKLLGRERGAAMEILRDACEKWGFFEIL 37

Banana 3 -----------MDSFPVIDMEKLLGRERGAAMEILRDACEKWGFFEIL 37

Banana 4 ----------MDSFPVIDMEKLLGRERGAAMEILRDACEKWGFFEIL 37

Banana 5 -----------MDSFPVIDMEKLSGGERGAAMEILRDACEKWGFFEIL 37

Kiwi ---------MEAFPVIDMEKLNGEERAPTMEKIKDACENWGFFELV 37

Mas-ACO PRKYFATGKKERVMDSFPVIDMEKLLGRERGAAMEILRDACEKWGFFEIL 50 $: * * * *: * * * * * * *: * *: . * * * *: * * * * *::$

Banana 1 NHGISHDLMDEVEKVNKEQYNKCREQKFNEFAN-KALENADSEIDHLDWE 86

Banana 2 NHGISHYLMDEVEKVNKEQYNKCREQKFNEFAN-KALENADSEIDHLDWE 86

Banana 3 NHGISHDLMDEVEKVNKEQYNKCREQKFNEFAN-KALENADSEIDHLDWE 86

Banana 4 NHGISHDLMDEVEKVNKEQYNKCREQKFNEFAN-KALENADSEIDHLDWE 86

Banana 5 NHGISHDLMDEVEKVNKEQYNKCREQKFNEFAN-KALENADSEIDHLDWE 86
} 


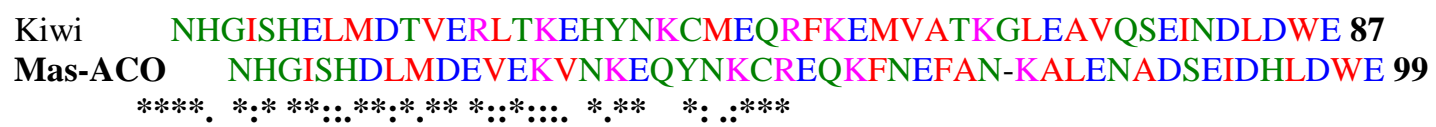

Banana 1 STFFLRHLPVSNISEIPDLDDQYRKAMKEFAAAIEKLAERLLDLLGENLE 136 Banana 2 STFFLRHLPVSNISEIPDLDDQYRKAMKEFAAAIEKLAERLLDLLGENLE 136 Banana 3 STFFLRHLPVSNISEIPDLDDQYRKAMKEFAAAIEKLAERLLDLLGENLE 136 Banana 4 STFFLRHLPVSNISEIPDLDDQYRKAMKEFAAAIEKLAERLLDLLGENWK 136 Banana 5 STFFLRHLPVSNISEIPDLDDQN--AMKEFAAEIEKVAERLLDLLGENLG 134 Kiwi STFFLRHLPVSNISEIPDLEQDHRKAMKEFAEKLEKLAEQLLDLLCENVG 137 Mas-ACO SSFFLRHLPVSNISEIPILMTSIGKALKVFAATIREAGTSVCSTCWVITV 149 $*: * * * . * * * * *::$ : . .:*** $: . .$.

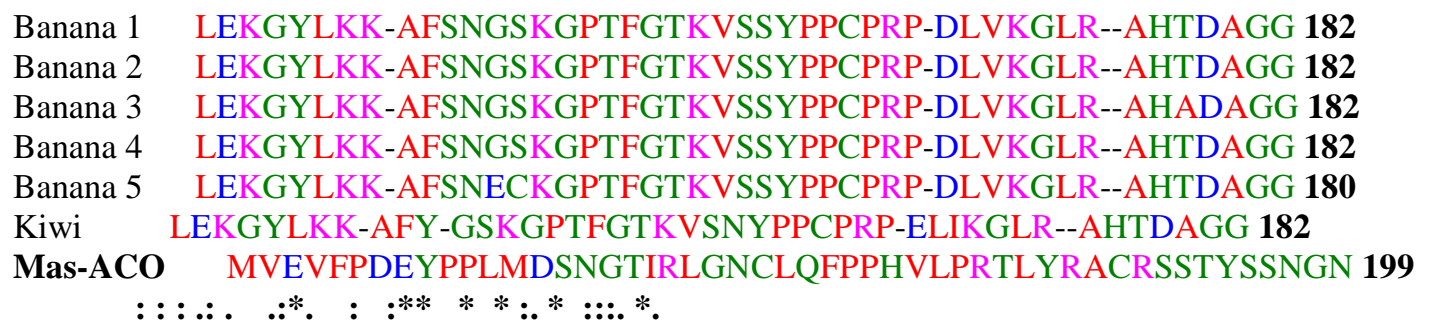

Banana 1 IILLFQDDQVSGLQFLKDGEWLDVPPMRHAIVVNLGDQLEVITNGKYKSV 232

Banana 2 IILLFQDDQVSGLQFLKDGEWLDVPPMRHAIVVNLGDQLEVITNGKYKSV 232

Banana 3 IILLFQDDQVSGLQFLKDGEWLDVPPMRHAIVVNLGDQLEVITNGKYKSV 232

Banana 4 IILLFQDDQVSGLQFLKDGEWLDVPPMRHAIVVNLGDQLEVITNGKYKSV 232

Banana 5 IILLFQDDQVSGLQFLKDGEWLDVPPIRHAIVVNLGDQLEVITNGKYKSV 230

Kiwi IILLFQDNKVSGLQLLKDGEWIDVPPMKHSIVINIGDQLEVITNGKYKSV 232

Mas-ACO FSFFFQDN---PLLVILAFPALTSPVIFRTSISLPTFFVDRTISPQDLDV 246

$::: * * * *:: \quad: *:::$ : : .: ::

Banana 1 VHRVVAQTDGNRMSIASFYNPGSDAVIFPAPALVEKEA---EEKKEVYPR 279

Banana 2 VHRVVAQTDGNRMSIASFYNPGSDAVIFPAPALVEKEA---EEKKEVYPR 279

Banana 3 VHRVVAQTDGNRMSIASFYNPGSDAVIFPAPALVEKEA---EEKKEVYPR 279

Banana 4 VHRVVAQTDGNRMSIASFYNPGSDAVIFPAPALVEKEA---EEKKEVYPR 279

Banana 5 VHRVVAQTDGNRMSIASFYNPGSDAVIFPAPALVEKEA---EEKKEVYPR 277

Kiwi MHRVIAQPDGNRMSIASFYNPGSDAVMYPAPALVDKEE---DQQKQVYPK 279

Mas-ACO NDIAHSDPDSDVLYLLCLFSPMILSLHISSSCFLLISLYAPLCDLYPFSG 296

..:*. : : :::* :: : :: . :

Banana 1 FVFEDYMKLYVGHKFQAKEPRFEAMKAMEAVAT-HPIATS- 318

Banana 2 FVFEDYMKLYVGHKFQAKEPRFEAMKAMEAVAT-HPIATS- 318

Banana 3 FVFEDYMKLYVGHKFQAKEPRFEAMKAMEAVAT-HPIATS- 318

Banana 4 FVFEDYMKLYVGHKFQAKEPRFEAMKAMEAVAT-HPIATS- 318

Banana 5 FVFEDYMKLYVGHKFQAKEPRFEAMKAMEAVAT-HPIATS- 316

Kiwi FVFEDYMKLYAGLKFQAKEPRFEAMKAMENAVNLGPIATI- 319

Mas-ACO TLSRVHMLECCNSTCLQNAFRVESSDFSSHSNYLQYYFTSS 337

$: .: * \quad$. : **:. * *

Figure 2: Multiple sequence alignment was done for the deduced amino acid sequence of Mas ACC oxidase protein and sequences encoding ACC oxidase from banana 1 (Hsien Jin Chiao TrEMBL code Q43547), banana 2 (Hsien Jin Chiao, Q6LC46), banana 3 (Grand nain, O49892), banana 4 (Q70BE4), banana 5 (Q70Y37) and kiwi (Actinidia chinensis, P31237) from CLUSTALW from www.ebi.ac.uk/clustalw. 


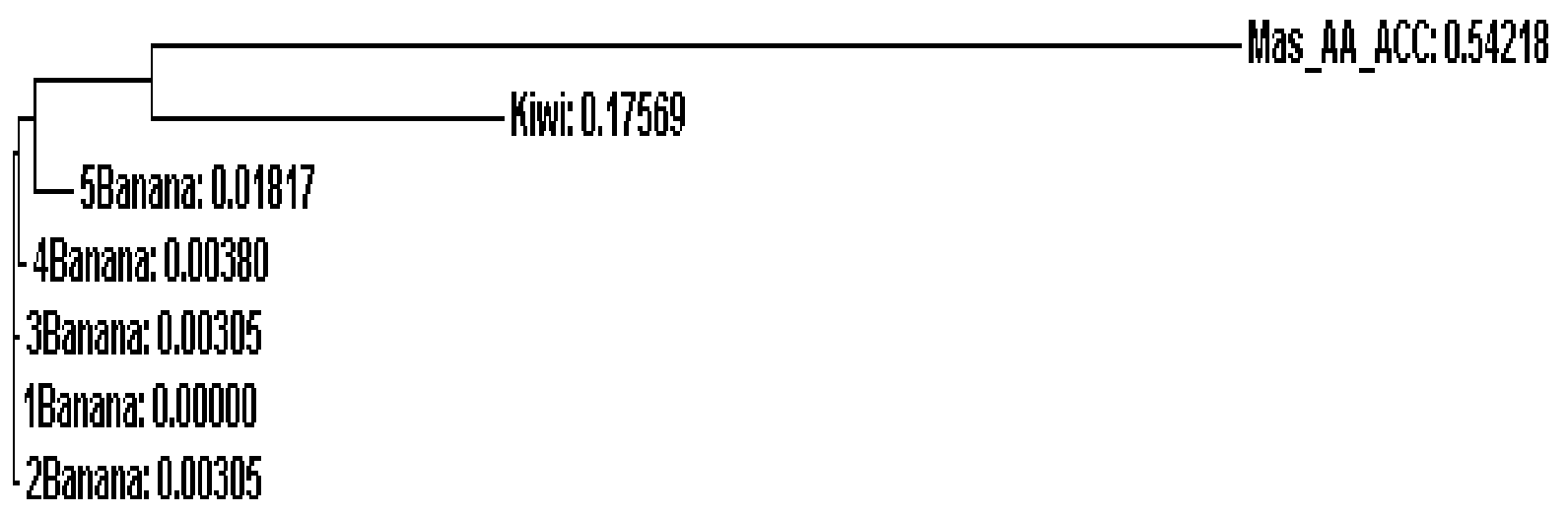

Figure 3: Phylogenetic tree shows the relationship between Mas ACC oxidase and ACC oxidase from significant homologies.
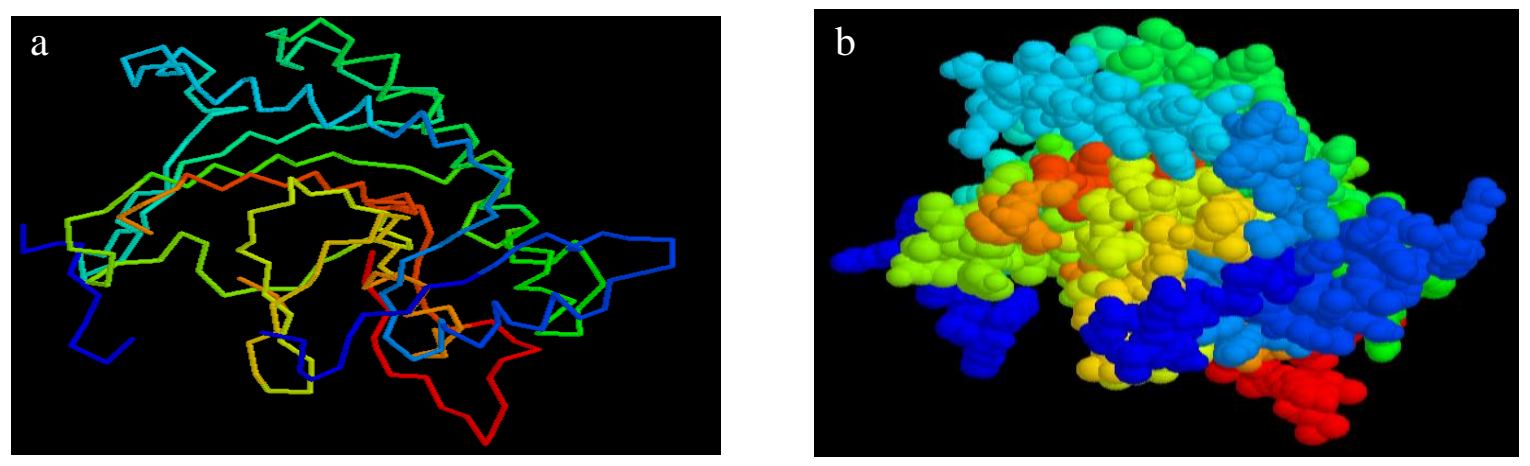

Figure 4: 3-D backbone (a) and spacefill model (b) structure of Mas ACO protein generated by a 3- state prediction (Helix/Strand/Coil).

\section{DISCUSSION}

A genomic sequence encodes ACO was isolated by RT-PCR approach from the Mas (AA) diploid. The $\mathrm{ACO}$ has been shown to require ascorbate and iron as cofactors. As in vivo, the purified enzyme requires $\mathrm{CO}_{2}$ for activity and the enzyme displayed an absolute requirement for Ferum (II) ion and ascorbate. The stoichiometry of the enzymatic reaction was determined as ACC + ascorbate $+\mathrm{O}_{2} \rightarrow$ $\mathrm{C}_{2} \mathrm{H}_{4}+\mathrm{HCN}+\mathrm{CO}_{2}+$ dehydroascorbate $+2 \mathrm{H}_{2} \mathrm{O}$. ACO also can be isolated in soluble form and these discrepancies can be reconciled by the interpretation that native ACO is located in both the cytosol (major compartment) and membranous fractions (minor compartment). Further analysis on Mas (AA) ACO protein sequence through InterProScan showed that the sequence contains a region which encodes a protein from iron/ascorbate-dependent oxidase superfamily. This finding supports that Mas (AA) ACO needs Ferum (II) ions and ascorbate as co- factor and concurrently oxidized to dehydroascorbate in an amount equivalent to that of ethylene produced. Homology comparisons for Mas (AA) ACO protein sequence using BLASTp shows that it has more than 90\% significant homologous gene which is from Banana 1 (Hsien Jin Chiao TrEMBL code Q43547), Banana 2 (Hsien Jin Chiao, Q6LC46), Banana 3 (Grand nain, O49892), Banana 4 (Q70BE4), Banana 5 (Q70Y37) and Kiwi (Actinidia chinensis, P31237). Multiple gene alignment was done using ClustalW to obtain consensus for the sequence homologous gene which is (P-V-I-[DN]-M-E-K-L-X-G-x-E-R-[AEGS]$x-[A T]-M-E-x-[I L]-x-D-A-C-E-x-W-G-F-F-E-$ $\mathrm{x}(0,1)-\mathrm{L}-\mathrm{x}(0,1)-\mathrm{N}-\mathrm{H}-\mathrm{G}-\mathrm{I}-[\mathrm{PS}]-\mathrm{x}(2)-\mathrm{L}-[\mathrm{LM}]-\mathrm{D}-[\mathrm{ET}]-$ $\mathrm{V}-\mathrm{E}-[\mathrm{KR}]-[\mathrm{LMV}]-[\mathrm{NT}]-\mathrm{K}$ ) where this consensus gives out two transmembrane helices. This finding was strengthened where ACO on Arabidopsis binds ethylene with the help of a copper cofactor that is bind in the transmembrane domain (Schaller, 2003). 


\section{CONCLUSION}

Based on this finding we can deduce that most of the ACO in climacteric fruit is genetically conserved which requires Ferum (II) ions and ascorbate as cofactor to be part of the ethylene biosynthesis.

\section{REFERENCES}

1. Abeles FB, Morgan PW and Saltveit ME Jr (1992). Ethylene in plant biology, second edition. Academic Press, New York.

2. Altschul SF, Gish W, Miller W, Myers EW and Lipman DJ (1990). Basic local alignment search tool. J. Mol. Biol. 215:403-410.

3. Christoffersen RE, McGarrey DJ and Savarese P (1993). Biochemical and molecular characterization of ethylene forming enzyme from avocado. In: Cellular and MolecularAspects of the Plant Hormone Ethylene (eds. Pech JC, Latche A and Balague C). Kluwer, 65-69.

4. Fernandez-Maculet JC and Yang SF (1992). Extraction and partial characterization of the ethylene-forming enzyme from apple fruit. Plant Physiol. 99: 751-754.

5. Fernandez-Maculet JG, Dong JG and Yang SF (1993). Activation of 1-aminocyclopropane -1carboxylate oxidase by carbon dioxide. Biochem. Biophys. Res. Commun. 193:1168-1173.

6. Gasteiger E, Gattiker A, Hoogland C, Ivanyi I, Appel R.D and Bairoch A (2003).
ExPASy: the proteomics server for in-depth protein knowledge and analysis. Nucleic Acids Res. 31:3784-3788.

7. Kelley LA and Sternberg MJE (2009). Protein structure prediction on the web: a case study using the Phyre server. Nature Protocols 4, 363 371

8. Lieberman M (1979). Biosynthesis and action of ethylene. Ann. Rev. Plant Physiol. 30: 533-591.

9. Liu JJ, Goh CJ, Loh CS, Liu P and Pua EC (1998). A method for isolation of total RNA from fruit tissues of banana. Plant Mol. Biol. Reptr. 16: 87.

10. Pathak N, Asif MH, Dhawan P, Srivastava MK and Nath P (2003). Expression and activities of ethylene biosynthesis enzyme during ripening of banana fruits and effect of 1-MCP treatment. Plant Growth Regulation 40:11-19.

11. Sayle R and Milner-White E J (1995). RasMol: Biomolecular graphics for all. Trends in Biochemical Sciences (TIBS) 20(9):374.

12. Schaller GE and Kieber JJ (2003). Ethylene: In: The Arabidopsis Book (eds. Somerville C and Meyerowitz E) American Society of Plant Biologists. Rockville, MD.

13. Ververidis P and John P (1991). Complete recovery in vitro of ethylene-forming enzyme activity. Phytochemistry 30: 725-727.

14. Yang SF and Hoffman NE (1984). Ethylene biosynthesis and its regulation in higher plants. Ann. Rev. Plant Physiol. 35: 155-189. 